\title{
What should I do if I Want to Start and Academic Research Career?
}

\author{
¿Qué Debo hacer si Quiero Comenzar la Carrera Académica de investigación?
}

Fuentes, R. ${ }^{1} \&$ Aravena, Y. $^{2}$

FUENTES, R. \& ARAVENA, Y. What should I do if I want to start and academic research career?. Int. J. Odontostomat., 15(4):1049-1052, 2021.

ABSTRACT: The incorporation of young researchers to universities today poses challenges and reflections. Several concepts that should be kept in mind when starting an academic career are analyzed, with an emphasis on research. Adequate postgraduate training, the type of higher education institution, contractual forms, insertion and interaction with groups, time dedicated to research, equipment available for research and research funds are concepts that are analyzed to guide young researchers in the beginning of an academic career at a university.

KEY WORDS: academic research career.

\section{INTRODUCTION}

Research has been fundamental in the development of human civilisation. On the other hand, universities have had a role in the advancement of knowledge since its creation. Thus, academic research has grown into one of the most important activities within modern universities establishing their innovative role in society. In Chile, research has been acknowledged as an essential mission for universities by law (Ministerio de Educación, 2018a,b) ensuring its place as a differentiating element among other types of higher education institutions. This view is reinforced through the national accreditation scheme where research, even when not mandatory, is expected from complex universities (Comisión Nacional de Acreditación, 2018).

Universities usually propose and set goals for their academics in order to accomplish its institutional vision. These goals led young academics to progress in their careers within the institution improving their academic positions, stability and salary over time. The areas of development for academics include undergraduate and graduate teaching, external relations, management, and research. The latter being one of the most important to apply to higher academic or directive positions.

Early career researchers and academics joining a University must understand from the beginning what is expected of them. This might vary according to the characteristics of each institution. Complex universities will seek professionals with demonstrated high professional capabilities to do undergraduate teaching, as well as professionals interested in an academic career to do research and other university tasks, where the professional development of these new academics will be linked to their research productivity.

The aforementioned context makes important that young professionals wishing to start an academic research career understand the elements of this complex competitive work environment to decide how to plan their career giving the necessary importance to the different areas of academic work and particularly to research. The aim of this article is to highlight key points to consider when starting research activities within a university.

\footnotetext{
${ }^{1}$ Departamento de Odontologia Integral, Facultad de Odontología, Universidad de La Frontera, Chile.

${ }^{2}$ Escuela de Odontología, Facultad de Odontología, Universidad de La Frontera, Chile.
} 
Postgraduate studies. A first key aspect to consider is the need to undertake postgraduate studies. Undergraduate courses do not always teach essential skills for research so they must be complemented with pertinent postgraduate studies. However, due to the wide offer on postgraduate programmes available, it is important to examine what type of postgraduate programmes are the most appropriate to acquire the skills needed in the research area of interest that will allow those looking to start their career to join established research units.

A PhD (Doctor in Philosophy) degree is the preferred option, as it gives the graduated professional the skills to do autonomous research. However, when a $\mathrm{PhD}$ is not possible, a master's degree is another good alternative. When deciding on a master degree it is important to differentiate between those with an academic or professional focus. Academic masters are recommended for those interested in research as they have and research-oriented syllabus and teach essential skills to successfully integrate research teams. In this sense, it is highly recommended to examine the syllabus of the programme of interest, the research topics available, its activities and the prospective results that can be accomplished by the end of the programme. Also, it is important to look at the programme's teaching staff to examine whether they have suitable research experience. For this purpose, it is recommended to explore the research projects they have led as well as their published articles in indexed journals. A final aspect to consider is that postgraduate degrees should meet the requirements stablished by the National Accreditation Commission (CNA) for postgraduate programmes in Chile. For those interested in international programmes it is also recommended to check their accreditation standards.

There are different scholarships and schemes to obtain financial support for postgraduate studies. In Chile, universities may offer partial or total scholarships for their programmes. Also, the 'National Research and Development Agency' (Spanish Acronym ANID) offer scholarships for national and international masters and doctoral studies under the 'Becas Chile' funding scheme. Currently, there are five types of national scholarships for postgraduate studies available and nine for international studies (Agencia Nacional de Investigación y Desarrollo, 2020a). Each scholarship has their own selection criteria, application deadlines, benefits, duration and retribution so it is important to carefully examine the scholarship of interest for a successful application. 'Becas Chile' national master scholarship is often the most competitive within the scheme due to the high number of applicants where in 2020 only $14.5 \%$ of applications were granted a scholarship (Agencia Nacional de Investigación y Desarrollo, 2020b), followed by 'Becas Chile' national $\mathrm{PhD}$ where $38.1 \%$ of applicants were successful in 2020 (Agencia Nacional de Investigación y DesarroIlo, 2020c). This scenario highlights the importance of planning the application and obtain relevant experience in order to fulfil the selection criteria as accurately as possible.

Institutional membership. A second element that early career researchers should consider is institutional membership, particularly, the importance given by the institution to research as not all universities grant the same relevance to this area. The university accreditation results can provide an overview regarding research development within the institution. Now a day postgraduate is a mandatory aspect of the acreditation process minwhile research is an optional area of accreditation and thus, they vary across institutions. In Chile, of 57 existing universities, 25 are accredited in research by the CNA and only 14 in postgraduate education (Comisión Nacional de Acreditación).

It is also important to consider that each university has its own organisational structure. This might include faculties, departments, schools and/or centres. It is helpful to understand the internal structure in order to identify if the position where the researcher is adjoined is the best suited to achieve their objectives. In this sense, the department or laboratory must do research in the area of interest as well as having the equipment and funding necessary to accomplish research tasks (i.e. infrastructure, laboratories, protected schedules for research, etc.). When the institution or laboratory does not fully match the new researcher objectives, it is sometimes necessary to create a more adequate space.

Research Group working relation. Human relationships are complex. This complexity is even greater in competitive environments such as within academic research. Understanding the team dynamics, its goals, and the relationships among its members and with their leaders is fundamental when joining research teams to accomplish high performance in a shorter time. In this sense, when joining a team, it is important to understand what is expected of the new researcher as each member must know their role instead of guessing it. This is not always easy and conflict might arise when a member does not fulfil their role through the expected tasks or leadership. The role within the 
research team should take priority over personal interests. It is recommended to be honest, to ask first about the team goals and to clarify personal interests as sometimes these might not be compatible. When there are differences between their personal interests and the team goals, the researcher should decide whether is possible to harmonise both or if it is better to search for a better fitted team.

Research time. This is another relevant aspect, especially for those without a full-time contract in the university of choice. This must not be confused with working hours contracts within the same institution. It is important to understand the contract and the agreed commitments and results expected from the hiring institution as not all universities ask their teachers or professors to do research. Also, funding sources and research spaces might not be available to all contract types as they may only be available to certain positions.

Equipment. This is a complex dimension. Does the institution have the physical space to do research? Do they have proper laboratories? Is it possible to have access to said laboratories as an early career researcher? These questions need to also be examined together with the research team dynamics where the researcher wants to join. Is the research team looking for applicants? Adding new members is not mandatory and they need to ensure that the new addition has the appropriate academic background as well as time and disposition to join the team.

When being offered the opportunity to work in a laboratory, the responsibility and care that the early career researcher shows towards the equipment and tasks will usually be taken into consideration when deciding on long term activities. In this sense, it is advantageous if the new researcher can contribute to the laboratory with equipment or supplies for their own research as well as the team needs through applications to funding sources. The contribution to the renovation and maintenance of the equipment through competitive funds is relevant and always welcome by laboratories.

\section{Funding}

All research projects need some type of funding, and thus, the skills and opportunity to apply and obtain resources from scholarships and other sources become highly relevant. A good postgraduate programme should teach skills to develop successful research proposals. In this line of though, every researcher should always pay attention to funding opportunities for themselves and their teams not matter their career stage. An early career researcher is expected to obtain funding for projects related to the laboratory where they are enrolling.

On the other hand, consolidated research teams are more likely to be awarded funding. In this sense, a well-planned long-term strategy is key to consolidate research teams by acquiring the necessary background in research that will be assessed by funding bodies through the application process. Applying to funds when not meeting the selection criteria will only be a waste of efforts and resources.

Some important aspects to include when applying for funding is considering a fee professional translation of the futuro article or its revision by editorial teams oriented to the specific journal where it is desired to publish. Also, the fees to publish with the Open Access option as it increases visibility and citation of published studies. When choosing where to publish, researchers must be careful with predatory journals as these do not follow established scientific publication standards such as peer-review or an editorial board hindering the research legitimacy (Bartholomew, 2014).

It is important to decide the journal of interest from the beginning of the research project, because in many cases publishing fees can be covered by the funding bodies through the project budget or through other institutional mechanisms. If it is not possible to finance publishing fees, this must be acknowledged from the beginning in order to analyse alternatives and avoid problems later in the project.

Supporting human resources. It is important to know if there are qualified human resources to support researchers and funds to cover its associated costs. For example, statistical experts for complex analyses, veterinarians when working with animal samples or technical workers in research laboratories. Sometimes, not having proper support makes the research topic unfeasible.

\section{CONCLUSIONS}

When deciding to move forward in research, and considering the competitiveness of the scientific research field, each early career researcher must at least ponder about the dimensions raised in this article 
including postgraduate studies, institutional membership, group interactions, research time, available equipment, funding and supporting human resources and plan accordingly to ease the start of a research career and to accomplish the expected outcomes.

FUENTES, R. \& ARAVENA, Y. Que debo hacer si quiero comenzar la carrera académica de investigación?. Int. J. Odontostomat., 15(4):1049-1052, 2021.

RESUMEN: La incorporación de jóvenes investigadores a las universidades hoy en día plantea desafíos y reflexiones. Se analizan varios conceptos que se deberían tener presentes al momento de comenzar una carrera académica, con énfasis en la investigación. La adecuada formación de posgrado, el tipo de institución de educación superior, formas contractuales, inserción e interacción con los grupos, tiempo dedicado a la investigación, equipamiento disponible para las investigaciones y fondos de investigación son conceptos que se analizan para orientar a jóvenes investigadores en el inicio de una carrera académica en una universidad.

PALABRAS CLAVE: carrera de investigación.
Ministerio de Educación. Ley 21.094. Sobre Universidades Estatales. Santiago de Chile, Biblioteca del Congreso Nacional de Chile, 2018b. Disponible en: http://bcn.cl/2ep3j

Corresponding author:

Prof. Dr. Ramón Fuentes Fernández

Research Centre for Dental Sciences

Dental School

Universidad de La Frontera

Av. Francisco Salazar 1145

Temuco

CHILE

E-mail: ramon.fuentes@ufrontera.cl

\section{REFERENCES}

Agencia Nacional de Investigación y Desarrollo (ANID). Becas para Estudios de Postgrado en Chile y en el Extranjero. Programa Formación de Capital Humano Avanzado. Oferta Becas. Santiago de Chile, Agencia Nacional de Investigación y Desarrollo (ANID), Gobierno de Chile, 2020a. Disponible en: https:// www.conicyt.cl/becasconicyt/postulantes/oferta-becas/\#tab-02

Agencia Nacional de Investigación y Desarrollo (ANID). Resultados del Concurso de Becas de Doctorado Nacional. Santiago de Chile, Subdirección de Capital Humano, Agencia Nacional de Investigación y Desarrollo (ANID), Gobierno de Chile, 2020b. Disponible en:https://app.powerbi.comview?r=eyJrljoiN2Y 4ZmFkYTEtMTlyZSOOMiA5LWJhMZktYmRIM2U3NmEzZmJhlimidCI6ImU3M2 FmMWRILWU5ZTYYNGMOOS1iMWUXLWZJNjg3ZjM2MjYONylsImMiOjR9

Agencia Nacional de Investigación y Desarrollo (ANID). Resultados del Concurso de Becas de Magister Nacional. Santiago de Chile, Subdirección de Capital Humano, Agencia Nacional de Investigación y Desarrollo (ANID), Gobierno de Chile, 2020c. Disponible en: https://app.powerbi.comview?r=eyJrljoiYzBkMmFm ZWMTYjFiNC00YzU4LWI1MzgtZTI3N2YwODc1MjEyliwidCI6ImU3M2 FmMWRILWU5ZTYtNGMOOS1iMWUXLWZJNjg3ZjM2MYYONyIsImMiOjR9

Bartholomew, R. E. Science for sale: the rise of predatory journals. J. R. Soc. Med., 107(10):384-5, 2014.

Comisión Nacional de Acreditación (CNA). Barómetro del Aseguramiento de la Calidad de la Educación Superior. Santiago de Chile, Comisión Nacional de Acreditación, 2018. Disponible en: https:/ /investigacion.cnachile.cl/archivos/cna/documentos/ 65b_Barometro-CNA-2.pdf

Ministerio de Educación. Ley 21.091. Sobre Educación Superior. Santiago de Chile, Biblioteca del Congreso Nacional de Chile, 2018a. Disponible en: http://bcn.cl/2ciws 